\title{
PENGEMBANGAN LEMBAR KERJA PESERTA DIDIK BERBASIS CTL PADA MATERI FLUIDA DINAMIS SMA KELAS XI
}

\author{
Ayu Safitri \\ Eko Suyanto \\ Ismu Wahyudi \\ Pendidikan Fisika, FKIP, Universitas Lampung \\ Email: ayusafitri354@gmail.com
}

\begin{abstract}
Abstrak
Model pembelajaran CTL merupakan model pembelajaran yang menekankan kerjasama peserta didik dalam kelompok. Peserta didik diberikan tugas di dalam kelompoknya, sehingga setiap peserta didik memiliki tanggungjawab untuk menyelesaikan tugas yang diberikan oleh guru. Bertanggungjawab dan bekerjasama merupakan salah satu sikap sosial yang dapat melatih aspek afektif peserta didik. Penelitian pengembangan ini bertujuan untuk mengembangkan lembar kerja peserta didik berbasis $C T L$ pada materi fluida dinamis yang dapat digunakan oleh peserta didik jenjang pendidikan SMA kelas XI tervalidasi. Penelitian ini juga dilakukan untuk mengetahui kemenarikan, kemudahan, dan kemanfaatan produk yang dikembangkan. Penelitian pengembangan mengacu pada desain penelitian dan pengembangan (R \& D) menurut Sugiyono, dengan prosedur pengembangan yang terdiri dari analisis kebutuhan, pengumpulan informasi, desain produk, validasi produk, revisi produk, dan uji coba produk. Produk akhir yang dihasilkan kemudian diberikan skor oleh ahli materi dan ahli desain yang telah dikonversi dalam pernyataan kualitatif. Uji ahli meteri dan uji ahli desain memperoleh kriteria sangat baik. Produk akhir juga memperoleh skor dari responden, dengan pernyataan kualitatif untuk uji kemenarikan adalah sangat menarik, uji kemudahan dengan kriteria sangat mudah, dan uji kemanfaatan dengan kriteria sangat bermanfaat.
\end{abstract}

Kata Kunci: $C T L$, Fluida Dinamis, Lembar Kerja Peserta Didik.

\section{PENDAHULUAN}

Pendidikan memiliki pengaruh terhadap moral peserta didik. Berdasarkan penelitian (Maidantius, 2014) menyatakan bahwa terdapat kesenjangan antara penanaman nilainilai sosial yang baik dan benar di sekolah dalam proses pendidikan, namun di masyarakat sebagai lapangan pendidikan yang merupakan 
A, Safitri., E, Suyanto., I, Wahyudi. - Pengembangan Lembar Kerja ...

salah satu tempat untuk baik. Kecerdasan emosional yang mempraktikkan pendidikan tidak baik pada diri peserta didik memberikan nilai-nilai etika yang diharapkan mampu mengendalikan benar dalam dunia pendidikan. degradasi moral, selain itu proses Misalnya, di sekolah peserta didik diajarkan tentang hal yang baik dan benar, tetapi di rumah atau lingkungan di mana peserta didik itu berada selalu memberikan teladan yang tidak baik, sehingga dilema penanaman nilai moral berakibat pada terjadinya krisis moral. Pengaruh kesenjangan terhadap moral ini akan terus berlangsung dan menghasilkan kerusakan moral bagi generasi selanjutnya.

Kesenjangan moral pada peserta didik ini merupakan suatu permasalahan tersendiri bagi dunia pendidikan. Guna memperbaiki moral peserta didik dan mencapai tujuan pendidikan nasional, diperlukan model pembelajaran yang dapat menunjang pendisiplinan karakter peserta didik melalui pembelajaran yang mengutamakan kerjasama. Pembelajaran yang mengutamakan kerjasama dilakukan agar setiap peserta didik tak hanya cerdas dalam segi kognitif, tetapi juga memiliki tingkat kecerdasan emosional yang pembelajaran juga dirancang agar kegiatannya berpusat pada peserta didik (student center). Salah satu model pembelajaran yang dapat menunjang tujuan ini adalah model pembelajaran collaborative teamwork learning (CTL).

Proses belajar mengajar tidak dapat terlepas dari penggunaan media pembelajaran. Salah satu bentuk media yang dapat dikembangkan untuk melatih peserta didik lebih aktif dalam belajar adalah lembar kerja peserta didik (LKPD). Menurut (Trianto, 2010) LKPD adalah panduan yang digunakan untuk melakukan kegiatan penyelidikan atau pemecahan masalah.

Salah satu materi pokok pada mata pelajaran fisika adalah fluida dinamis. Pada materi ini, dibutuhkan pemahaman konsep yang baik oleh peserta didik. Pemahaman konsep yang baik bagi peserta didik dibutuhkan karena pada materi fluida dinamis terdapat perluasan persamaan bernoulli. Penyampaian materi ini 
belum efektif jika hanya diberikan dengan metode ceramah.

Berdasarkan analisis kebutuhan yang dilakukan dengan memberikan angket kepada beberapa peserta didik di salah satu sekolah di Bandar Lampung, diketahui bahwa belum terdapat LKPD berbasis CTL yang dikembangkan pada materi fluida dinamis. Berdasarkan analisis kebutuhan diperoleh data bahwa $82,32 \%$ peserta didik menyatakan model pembelajaran yang digunakan guru cen-derung merupakan model konvensional. Sebanyak 71,36 \% peserta didik mengakui bahwa proses pembelajaran belum menekankan pada pemahaman konsep, proses mencari tahu serta kerja sama antar anggota kelompok maupun kerja sama antar kelompok. Penerapan proses pembelajaran tersebut mengakibatkan tujuan pembelajaran yang diharapkan belum maksimal.

Pencapaian tujuan pembelajaran yang maksimal membutuhkan adanya media pembelajaran untuk menunjang kegiatan belajar mengajar, oleh karena itu diperlukan pengembangan LKPD berbasis CTL pada materi fluida dinamis untuk SMA Kelas XI.
Secara umum, menurut (Muhson, 2010) media pembelajaran merupakan wahana penyalur pesan dan informasi belajar. Secara lebih khusus (Nugroho et al., 2013) menyatakan bahwa media pembelajaran adalah alat bantu yang digunakan untuk menyampaikan materi pembelajaran kepada peserta didik. Menurut (Handikha et al., 2013) mengemukakan bahwa media pembelajaran sangat penting, sehingga dapat menumbuhkan motivasi belajar bagi peserta didik. Secara garis besar dapat disimpulkan bahwa LKPD merupakan media pembelajaran yang digunakan sebagai salah satu alat bantu untuk membangun pengetahuan peserta didik.

LKPD yang baik adalah LKPD yang dapat digunakan untuk menilai ketiga aspek pembelajaran yang meliputi aspek kognitif, afktif dan psikomotorik. Salah satu model pembelajaran yang dapat menilai ketiga aspek tersebut adalah model pembelajaran $C T L$.

Berdasarkan penelitian (Jiwa et al., 2013) terdapat perbedaan motivasi belajar antara peserta didik yang 
menggunakan model Pembelajaran

CTL dengan model pembelajaran konvensional. Peserta didik yang menggunakan model pembelajaran CTL pada proses pembelajaran memiliki motivasi dan hasil belajar lebih tinggi dibandingkan dengan peserta didik yang belajar dengan model konvensional. Menurut (Darmayanti et al., 2013) model pembelajaran CTL mampu mengoptimalkan kegiatan pembelajaran, keterampilan proses sains dan pemahaman konsep peserta didik.

Menurut (Frances, 2008) tahapan CTL antara lain adalah forming, stroming, norming, performing, dan adjouring. Secara garis besar, berdasarkan pendapat beberapa ahli dapat disimpulkan bahwa model pembelajaran $\quad C T L \quad$ mampu mengoptimalkan pembelajaran dan menitikberatkan pada kerjasama antar individu dalam kelompok, maupun antar kelompok.

\section{Pengembangan LKPD yang} dilakukan memiliki beberapa bagian. Bagian LKPD meliputi cover, kata pengantar, daftar isi, kompetensi dasar, kompetensi inti, tujuan pembelajaran, indikator pem- belajaran, dan materi esensial fluida dinamis yang meliputi debit, kontinuitas dan asas bernoulli.

\section{METODE}

Penelitian Metode penelitian yang digunakan adalah Research and Development menurut pendapat (Sugiyono, 2011). Tahapan penelitian pengembangan menurut Sugiyono terdiri dari sepuluh langkah. Penelitian pengembangan dilakukan mengadopsi langkah penelitian pengembangan Sugiyono, akan tetapi dibatasi sampai pada tahap uji coba produk. Tahap awal penelitian pengembangan juga diubah menjadi analisis kebutuhan, hal ini dilakukan berdasarkan penyesuaian penelitian pengembangan yang dilakukan oleh peneliti. Secara lebih rinci, prosedur pengembangan penelitian ini adalah analisis kebutuhan, pengumpulan data, desain produk, validasi produk, revisi produk, dan uji coba produk.

Teknik pengumpulan data yang dilakukan dalam penelitian ini adalah dengan menggunakan metode angket. Metode angket digunakan ketika melakukan analisis kebutuhan, uji validitas produk, dan 
uji coba produk. Hasil dari nilai yang diperoleh kemudian dikonversi dalam bentuk pernyataan kualitatif untuk menentukan tingkat kemenarikan, kemudahan, dan kemanfaatan produk seperti pada tabel 1 .

Tabel 1. Konversi Skala Respon Uji Kemenarikan, Kemudahan dan

Kemanfaatan

\begin{tabular}{ll}
\hline Rerata Skor & Klasifikasi \\
\hline $3,26-4,00$ & Sangat \\
& Baik \\
$2,51-3,25$ & Baik \\
$1,76-2,50$ & Kurang Baik \\
$1,01-1,75$ & Tidak Baik \\
\hline
\end{tabular}

HASIL DAN PEMBAHASAN

Hasil penelitian pengembangan ini adalah LKPD berbasis CTL materi fluida di-namis tervalidasi. Kompetensi dasar yang digunakan pada LKPD ini adalah KD 3.3 yaitu mendeskripsikan prinsip fluida dinamis dan penerapannya dalam teknologi, serta KD 4.3 yaitu membuat proyek sederhana yang menerapkan prinsip fluida dinamis. Tahapan yang dilakukan pada penelitian pengembangan ini adalah (1) analisis kebutuhan, pengumpulan data, (3) desain produk, (4) validasi produk, (5) revisi desain dan (6) uji coba produk.

Penelitian ini dilaksanakan atas dasar analisis kebutuhan lapangan yang dilakukan peneliti. Analisis kebutuhan yang dilakukan oleh peneliti dilakukan dengan memberikan angket kepada 33 orang peserta didik dan seorang guru fisika kelas XII di salah satu SMA negeri di Bandar Lampung. Berdasarkan hasil analisis angket kebutuhan diperoleh hasil bahwa $82,32 \%$ peserta didik menyatakan model pembelajaran yang digunakan guru cenderung merupakan model konvensional. Sebanyak 71,36 $\%$ peserta didik mengakui bahwa proses pembelajaran belum menekankan pada pemahaman konsep, proses mencari tahu serta kerja sama antar anggota kelompok.

Setelah melaksanakan analisis kebutuhan, peneliti kemudian melakukan pengumpulan informasi. Pengumpulan informasi dilaksanakan 
dengan cara membaca beberapa jurnal terkait media pembelajaran, LKPD, model pembelajaran $C T L$ dan materi esensial fluida dinamis.

Berdasarkan hasil pengumpulan informasi, diperoleh beberapa komponen yang harus ada di dalam LKPD yang dikembangkan yaitu (1) materi yang dikembangkan pada LKPD difokuskan pada materi esensial topik fluida dinamis yang meliputi materi debit, kontinuitas dan penerapan asas bernoulli, diperlukan adanya contoh fenomena pada materi esensial yang meliputi debit, kontinuitas dan penerapan asas bernoulli, agar peserta didik memperoleh pembelajaran secara faktual, dan (3) diperlukan adanya kegiatan praktikum pada materi esensial yang meliputi debit, kontinuitas dan penerapan asas bernoulli, agar peserta didik memperoleh pembelajaran secara konseptual dan prosedural.

Pembuatan LKPD yang dikembangkan memiliki desain sebagai berikut, (1) cover yang memuat judul materi, gambar fenomena fluida dinamis, gambar ilustrasi percobaan, nama pengembang, nama pembimbing, kolom nama pemilik LKPD dan tingkat sekolah, (2) kata pengantar, (3) daftar isi, (4) daftar gambar, (5) daftar tabel, (6) kompetensi inti, (7) kompetensi dasar, (8) indikator, (9) tujuan pembelajaran, (10) kegiatan pembelajaran yang meliputi beberapa percobaan mengenai materi debit, kontinuitas dan penerapan asas bernoulli, (11) daftar rujukan.

Langkah selanjutnya adalah validasi produk. Validasi produk terdiri dari validasi materi dan vaidasi desain. Uji validasi produk dilakukan oleh dua orang dosen pendidikan fisika FKIP Universitas Lampung, dan seorang guru fisika SMA yang memiliki latar belakang teknologi pendidikan. Uji validasi produk dilakukan dengan memberikan angket kepada ahli materi dan ahli desain. Angket yang diberikan kepada ahli materi dan ahli desain terdiri dari beberapa pertanyaan terkait kelayakan materi dan desain produk yang dikembangkan oleh peneliti.

Angket uji ahli materi terdiri dari dua puluh pertanyaan dengan rincian sepuluh pertanyaan aspek kelayakan isi/materi, empat pertanyaan 
mengenai aspek kelayakan bahasa, dan enam pertanyaan mengenai aspek kelayakan penyajian materi. Sementara itu, pada penilaian ahli desain, terdiri dari sembilan belas pertanyaan, dengan rincian empat pertanyaan untuk desain sampul, tiga pertanyaan aspek tipografi sampul dan dua pertanyaan aspek ilustrasi sampul. Tipografi bagian isi terdiri atas tujuh pernyataan dan untuk aspek ilustrasi bagian isi terdiri atas tiga pernyataan. Hasil uji validasi ahli materi disajikan dalam tabel 2, sedangkan untuk hasil uji validasi desain disajikan pada tabel 3 .

Tabel 2. Hasil Validasi Ahli Materi

\begin{tabular}{llll}
\hline No & Aspek Penilaian & Skor & $\begin{array}{l}\text { Pernyataan } \\
\text { Kualitatif }\end{array}$ \\
\hline 1 & Kelayakan Isi/Materi & 3,69 & Sangat Baik \\
2 & Kelayakan Bahasa & 3,50 & Sangat Baik \\
3 & Kelayakan Penyajian & 3,67 & Sangat Baik \\
\hline
\end{tabular}

Tabel 3. Hasil Validasi Ahli Terhadap Desain Produk

\begin{tabular}{lllll}
\hline No & Bagian & $\begin{array}{l}\text { Aspek } \\
\text { Penilaian }\end{array}$ & Skor & $\begin{array}{l}\text { Pernyataan } \\
\text { Kualitatif }\end{array}$ \\
\hline 1 & Sampul & Desain & 3,92 & Sangat Baik \\
& & Tifografi & 3,45 & Sangat Baik \\
& & Ilustrasi & 3,50 & Sangat Baik \\
2 & \multirow{2}{*}{ Isi } & Tifografi & 3,67 & Sangat Baik \\
& & Ilustrasi & 3,78 & Sangat Baik \\
\hline
\end{tabular}

Berdasarkan tabel hasil validasi ahli terhadap materi dapat diketahui bahwa komponen materi dalam LKPD sangat baik untuk digunakan sebagai media pembelajaran alternatif bagi peserta didik .

Berdasarkan angket yang diisi oleh ahli materi diperoleh beberapa saran perbaikan yaitu (1) menambahkan gambar tabung sebelum terjadi kebocoran dan memberikan warna biru pada tabung, agar terlihat ilustrasi air di dalam tabung, (2) mengubah kegiatan forming pada kegiatan 2 dan menyamakannya dengan forming pada kegiatan 1 dan 3, dan (3) menggunakan gambar asli pada 
materi debit dan kontinuitas. peserta didik dengan kemampuan Berdasarkan angket yang telah sedang, dan satu orang peserta didik diberikan kepada ahli desain, dengan kecerdasan rendah. Tahap uji diperoleh saran perbaikan sebagai coba pemakaian produk pada peserta berikut (1) mengubah background didik ini berupa uji kemenarikan, sampul LKPD menggunakan gambar kemudahan dan kemanfaatan. Tujuan fenomena fluida dinamis pada kehidupan sehari-hari, memberikan bingkai pada bagian tepi LKPD agar terlihat lebih menarik, (3) mengubah ukuran tulisan pada judul sampul LKPD, (4) memperbaiki tata letak gambar pada sampul LKPD, dan (5) menyesuaikan ukuran kolom nama peserta didik pada bagian sampul LKPD.

Berdasarkan hasil uji ahli materi dan uji ahli desain diperoleh beberapa saran perbaikan dari validator ahli materi dan ahli materi baik dari segi penyajian materi maupun desain LKPD yang dikembangkan. Selanjutnya, saran perbaikan yang diberikan oleh ahli ini dijadikan acuan sebagai perbaikan produk.

Uji coba produk dilakukan kepada tiga orang peserta didik yang terdiri dari satu orang peserta didik dari uji coba pemakaian produk ini adalah untuk mengetahui kemenarikan, kemudahan dan kebermanfaatan LKPD berbasis $C T L$ pada materi fluida dinamis yang dikembangkan.

Ketiga peserta didik tersebut diberikan perlakuan yang sama yaitu pemberian produk LKPD materi fluida dinamis berbasis CTL yang dikembangkan. Selanjutnya, peserta didik tersebut diminta untuk mengisi angket yang telah disediakan oleh peneliti. Instrumen uji kemenarikan produk terdiri atas delapan pertanyaan, instrumen uji kemudahan produk terdiri atas enam pertanyaan, dan instrumen uji kemanfaatan produk terdiri atas lima pertanyaan. Hasil uji kemenarikan, kemudahan, dan kemanfaatan ditampilkan dalam tabel 4 . dengan kecerdasan tinggi, satu orang 
A, Safitri., E, Suyanto., I, Wahyudi. - Pengembangan Lembar Kerja ...

Tabel 4. Hasil Uji Kemenarikan, Kemudahan dan Kemanfaatan

\begin{tabular}{llll}
\hline No & Aspek Penilaian & Skor & Pernyataan Kualitatif \\
\hline 1 & Kemenarikan & 3,37 & Sangat Menarik \\
2 & Kemudahan & 3,38 & Sangat Mudah \\
3 & kemanfaatan & 3,40 & Sangat Bermanfaat \\
\hline
\end{tabular}

LKPD berbasis CTL materi fluida dinamis yang dikembangkan pada penelitian pengembangan ini sudah disesuaikan dengan saran perbaikan yang diberikan oleh para ahli. LKPD yang dikembangkan berbasis model pembelajaran $C T L$.

Model pembelajaran $C T L$ menekankan pada kerjasama antar peserta didik dalam melaksanakan kegiatan belajar mengajar dan memecahkan permasalahan. Kerjasama antar peserta didik yang dirancang pada produk yang dikembangkan, diharapkan mampu membuat peserta didik lebih mudah dalam menyelesaikan permasalahan dan dapat meningkatkan kinerja peserta didik dalam bekerja sama.

Penelitian relevan mengenai model pembelajaran $C T L$ dilakukan oleh (Darmayanti et al., 2013) yang menunjukkan bahwa model pembelajaran $\quad C T L \quad$ mampu mengoptimalkan kegiatan pembelajaran, sehingga mampu mengoptimalkan keterampilan proses sains dan pemahaman konsep peserta didik. Selanjutnya, dalam LKPD yang dikembangkan, disajikan beberapa contoh fenomena dan permasalahan dalam kehidupan sehai-hari yang merupakan penerapan dari materi fluida dinamis. LKPD yang dikembangkan juga dilengkapi dengan percobaan pada masingmasing kegiatan pembelajaran. LKPD yang dikembangkan diharapkan mampu menumbuhkan ketertarikan peserta didik dalam proses pembelajaran, sehingga dapat meningkatkan pengetahuan konsep materi yang diajarkan oleh guru.

Penelitian terdahulu yang membahas mengenai penyajian contoh fenomena dalam penyampaian materi dilakukan oleh (Wahyudin \& Isa, 2010) yang menyatakan bahwa, dalam melaksanakan proses pembelajaran, ketika pendidik menggunakan gambar dan contoh fenomena dalam menyampaikan 
materi pembelajaran diperoleh peneliti didasarkan pada skor masingpeningkatan tanggapan peserta didik terhadap pengajaran yang diberikan oleh pendidik dari $72,90 \%$ menjadi 76,81\%. Banyak peserta didik yang memberikan tanggapan positif terhadap pembelajaran yang dilakukan oleh pendidik, hal ini menunjukkan adanya rasa tertarik dan berminat dari peserta didik dalam melaksanakan kegiatan belajar mengajar.

Penelitian terdahulu yang membahas mengenai penyajian percobaan yang dilakukan pada saat penyampaian materi pembelajaran dilakukan oleh (Hamdani et al., 2012), yang menyatakan bahwa terdapat perbedaan pemahaman konsep peserta didik yang diberikan perlakuan penyampaian pembelajaran dengan menggunakan praktikum, dan tidak menggunakan praktikum. Kelas eksperimen yang melakukan praktikum saat proses pembelajaran memiliki nilai rata-rata postes lebih besar daripada kelas yang tidak melakukan praktikum saat proses pembelajaran.

Hasil uji validitas materi dan validitas desain yang dilakukan oleh masing pertanyaan pada instrumen uji ahli desain dan uji ahli materi. Pertanyaan yang ada pada instrumen mengacu pada penelitan terdahulu yang dilakukan oleh (Anggraini et al., 2016), yang menyatakan bahwa LKPD yang baik, memiliki bebrapa syarat diantaranya tata letak, susunan kalimat, dan gambar ilustrasi. Pertanyaan pada instrumen uji ahli materi dan uji ahli desain juga didasarkan pada penelitian yang dilakukan oleh (Ernawati \& Sukardiyono, 2017) yang menyatakan bahwa LKPD yang baik perlu memperhatikan segi penyajian materi dan tampilan.

Berdasarkan kedua penelitian terdahulu ini, peneliti menggolongkan aspek uji ahli meteri terdiri dari kelayakan materi/isi, kelayakan bahasa dan kelayakan penyajian. Aspek uji ahli desain meliputi tifografi, gambar dan ilustrasi.

LKPD yang dikembangkan memiliki beberapa kelebihan dan kekurangan. Kelebihan dari LKPD yang dikembangkan adalah disajikannya gambar fenomena kehidupan sehari-hari, disajikan 
orientasi masalah yang berkaitan dengan kehidupan seharihari, dan disajikannya panduan praktikum yang berkaitan dengan kehidupan seharihari. Kegiatan pembelajaran yang didesain dikerjakan secara berkelompok, sehingga dapat memudahkan peserta didik dalam memahami konsep esensial dari materi fluida dinamis. Kekurangan dari LKPD ini adalah, LKPD merupakan salah satu media cetak dalam proses pembelajaran, sehingga LKPD tidak praktis untuk dibawa oleh peserta didik.

\section{PENUTUP}

\section{Kesimpulan}

Simpulan dari penelitian pengembangan ini adalah diihasilkannya Lembar Kerja Peserta Didik (LKPD) Berbasis $C T L$ pada materi fluida dinamis SMA kelas XI sebagai media pembelajaran alter-natif yang sudah tervalidasi. Uji kemenarikan produk diperoleh dengan kriteria sangat menarik, uji kemudahan diperoleh dengan kriteria sangat mudah, dan uji kemanfaatan diperoleh dengan kriteria sangat bermanfaat.

\section{Saran}

Bagi guru yang menggunakan LKPD berbasis $C T L$ materi fluida dinamis ini diharapkan dapat mempersiapkan pembelajaran dengan baik, terutama waktu.

Bagi penelitian selanjutnya, akan lebih baik jika dilakukan penelitian lebih lanjut untuk mengetahui keefektifan LKPD berbasis CTL materi fluida dinamis.

\section{DAFTAR PUSTAKA}

Anggraini, R., Wahyuni, S., Lesmono, D. A. (2016). Pengembangan Lembar Kerja Siswa (LKS) Berbasis Keterampilan Proses Di SMAN 4 Jember. Jurnal Pembelajaran Fisika, 4(4), 350-356.

Darmayanti, N. W. S., Sadia, W., \& Sudiatmika, A. A. I. A. R. (2013). Pengaruh Model CTL Terhadap Kete-rampilan Proses Sains dan Pema-haman Konsep Ditinjau dari Gaya Kognitif. E-Journal Program Pascasarjana Universitas Pendidikan Ganesha, 3(2), 1-12.

Ernawati, L., Sukardiyono, T. (2017). Uji Kelayakan Pembelajaran Interaktif Pada Mata Pelajaran Administrasi Server. Electronics, Informatics, AND Vocational Education, 2(2), 25-32.

Frances, M. (2008). Stages of group development A PCP approach. Personal Construct Theory and Practice. 8(5), 10-18.

Hamdani, D., E. Kurniati., I. Sakti. (2012). Pengaruh Model Pembelajaran Generatif dengan Menggunakan Alat Peraga 
Terhadap Pe-mahaman Konsep Cahaya Kelas VIII Di SMP Negeri 7 Kota Bengkulu. Jurnal Exacta, $10(1), 8$.

Handikha, I. M. D., Agung, A.A.G., Sudhata, I. G. W. (2013). Pengembangan Multimedia Pembelajaran Interaktif Model Luther Pada Mata Pelajaran IPA Kelas VIII Semester Ganjil Tahun Pelajaran 2012/2013 Di SMP Negeri 1 Marga Kabupaten Tabanan. Jurnal Teknologi Pendidikan, 1(2), 1-10.

Jiwa, I. W. M., Atmadja, N. B., Yudana, M. (2013). Pengaruh Model CTL Terhadap Motivasi Dan Prestasi Belajar Sosiologi Siswa Kelas X SMA Negeri 1 Almapura. e- Journal Program Pascasarjana Universitas Pendidikan Ganesha Program Studi Administrasi Pendidikan, 2(4), 1-7.

Maidantius, T. (2014). Etika dalam Pendidikan : Kajian Etis Tentang Krisis Moral Berdampak pada Pendidikan. Jurnal Jaffray,12 (2), 235-242.

Muhson, A. (2010). Pengembangan Media Pembelajaran Berbasis Tekno-logi Informasi :Staf Pengajar Jurusan Pendidikan Ekonomi Universitas Negeri Yogyakarta. Jurnal Pendidikan Akuntansi Indonesia, 8(2), 1-10.

Nugroho, A. P., Raharjo, T., Wahyuningsih, D. (2013).

Pengembangan Media Pembelajaran Fisika Menggunakan Permainan Ular Tangga Ditinjau dari Motivasi Belajar Siswa Kelas VIII Materi Gaya. Jurnal Pendidikan Fisika, 1(1), 1-8.
Sugiyono. (2011). Metode Penelitian Kuantitatif, Kualitatif, Dan R\&D. Alfabeta, Bandung.

Trianto. (2010). Model Pembelajaran Terpadu. Bumi Aksara, Jakarta.

Wahyudin, S., A. Isa. (2010). Keefektifan Pembelajaran Berbantuan Multimedia Menggunakan Metode Inkuiri Terbimbing untuk Meningkatkan Minat dan Pemahaman siswa. Jurnal Pendidikan Fisika Indonesia, 6 (1), 3. 